\title{
Téoros
}

Revue de recherche en tourisme

\section{Ecotourism and Sustainable Development in Kenya: Opportunities and Challenges}

\section{Paul Omondi}

Volume 13, numéro 2, été 1994

Regards sur le tourisme dans les pays en développement

URI : https://id.erudit.org/iderudit/1077764ar

DOI : https://doi.org/10.7202/1077764ar

Aller au sommaire du numéro

Éditeur(s)

Université du Québec à Montréal

ISSN

0712-8657 (imprimé)

1923-2705 (numérique)

Découvrir la revue

Citer cet article

Omondi, P. (1994). Ecotourism and Sustainable Development in Kenya:

Opportunities and Challenges. Téoros, 13(2), 43-47.

https://doi.org/10.7202/1077764ar d'utilisation que vous pouvez consulter en ligne.

https://apropos.erudit.org/fr/usagers/politique-dutilisation/ 


\title{
Ecotourism and Sustainable Development in Kenya : Opportunities and Challenges
}

\author{
Paul Omondi"
}

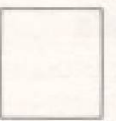

Ecotourism, alsocalled variously as nature tourism, alternative tourism, responsible tourism, and many others, is currently promoted in Kenya, like in other parts of the world, as a realistic way of protecting nature and integtating conservation with local development. The goal is to develop and promote new forms of tourism which will bring the greatest possible benefit to all the participants travellers, the host populations and the tourist business, without causing intolerable ecological and social change (Boo, 1990; Whelan, 1991). In the ecotourism approach, visitors are urged to adopt eco-code forms of behaviour in order to acquire a strong commitment to nature and be concerned with the welfare and integrity of the host communities (Western, 1993). Earnings from ecotourism is to be used to help create and maintain the resources that attract ecotourists and provide direct benefit to the local communities where theresources are located. Useof local resources, called ecotedniques, and local expertise is encouraged to reduce the effects on the environment. Tourists activities are to be small-scale, locally owned with consequently lowimport leakagesand a higher proportion of profits retained locally as opposed to the traditional tourism of large-scale, multinational ownership with high leakages (Cater, 1993).

While the idea and the opportunities of ecotourism cannot be denied, there are many challenges to be addressed if its benefits are to be achieved in Kenya. This article examines the role of ecotourism in sustainable development in Kenya and suggests how it can be planned so that it is both ecologically sensitive and economically productive to Kenyan communities both the government and the local people. The article focuses on two key components of the relationship between ecotourism and sustainable development: (1) the need to protect natural areas and

Mir. Paul Omondis doctoral candidate, Department of geography, McGill University, Montreal, Canada.

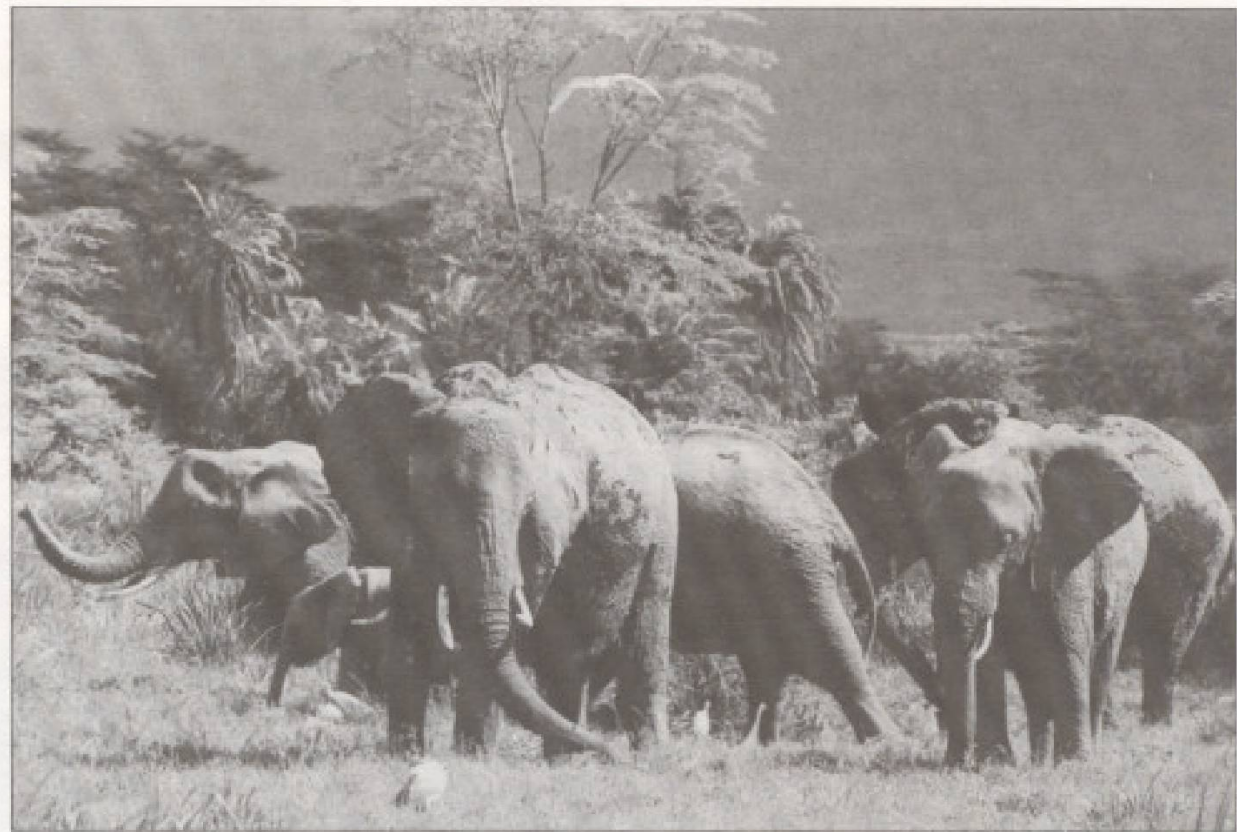

Herd of elephants just outisale.Amboseli National Park. Their future is threatened with the expanding human activities.

features that are the main attractions for ecotourists in Kenya, and (2) the need to promote development of the local communities who live in wildlife areas. The history of ecotourism in Kenya is traced and the major tourists attractions outlined. The role of tourism in Kenya's coonomy and the undesirable impacts of tourism on the environment are described. The potential benefitsofecotourism and challenges that need to be overcome if its benefits are to be realized are discussed. The main theme of the article is that ecotourism must be properly planned and managed if it is to truly contribute to sustainable development in Kenya. Otherwise, it may lead to unsustainable development and may in the end not be any different from the conventional tourism, if not worse. The ultimatesuccess of ecotourism will bemeasured in terms of its ability to minimise as far as possible, disturbance to the natural resources while at the same time involving and providing tourism benefits to the local communities.

Because the terms ecotourism and sustainable development are used differently, it is important to explain the meaning adopted in this article. Sustainable development is defined here as contained in the 1987 Brundtland Commission as $\approx$ development that meets the needs of the present without compromising the ability of future generations to meet theirs (WCED, 1987). Ecotourism is used broadly to include all natural resources and certain types of and culturally-based tourism as provided by Ziffer.

(Ecotourism) a form of tourism inspired primarily by the natural bistory of an area, including its indigenous cultures. The ecotourist visits relatively undeveloped areas in the spirit of appreciation, participation and sensitivity. The ecotourist practices a nonconsumptive use of wildlife and natural resources and contributes to the visited area tbrough labour or financial means aimed at directly benefiting the conservation of the site and the economic well-being of the local residents (Ziffor, 1989). 


\section{Development of ecotourism in Kenya}

Although there have been naturalists travellers visiting Kenya for a long time, their experience did not produce socio-economic benefits to the remote places they visited, nor did their activities intended as a tool for conserving natural areas, native cultures or endangered species. When then did ecotourism begin in Kenya? It is important to establish the point in time when Kenya started emphasizing the principles entailed in ecotourism so that later we will be able to measure whether we have really changed.

The conventional tourism began in Kenya at the end of the 19th century (around 1895 ) with the advent of colonialism. Before then, local indigenous Kenyans lived in harmony with nature. They killed game only as needed for food and rituals and never for pleasure (Olindo, 1991). The first generation of travellers to Kenya were attracted by trade prospects, mainly ivory trade, killing hundreds of thousands of elephants. The second generation were attracted by the big-game hunting expeditions. Wild animals were captured and killed for sport. One can therefore safely say that until the late 1940 s the link between tourism and wildlife in Kenya was founded on hunting (exploitation) rather than on viewing the animals, as it is today (Olindo, 1991). The concern for ecotourism began in Kenya in 1987 when the future of tourism industry and the need to conserve Kenya's natural resources and attractions as an economic imperative increased. Consequently, the Kenya Wildlife Service (KWS), a parastotal body, was established replacing the government departunent, the Wildlife Conservation and Management (WCMD). The KWS in conjunction with the Ministry of Tourism and Wildlife, assumed the mantle of conservation, management of wildlife resources, and the task of balancing the demands of national development, population pressure, conflicting land uses, tourism and national development objectives.

Kenya today is one of the world's foremost ecotourist attractions. About 700000 international tourists visit Kenya each year spending about $\$ 350$ million. There have been three distinct periods of tourism growth in Kenya: the late 1960's, 1976, and the mid-1980's. Tourist growth has been $5,7 \%$ per annum, while earning has been $15 \%$. Tourists to Kenya is projected to increase such that 1 million will visit the country per year by the year 2000 (KWS, 1990). This trend will overwhelm the ability of many areas some of which like Masai Mara and Amboseli are already showing signs of over-stress. Most ecotourist visiting Kenya come from Europe, North America and other developed countries. Kenya also have 300000 domestic tourists a year.

The main tourists attractions are the wildlife viewing mainly in the national parks and reserves, and the coastal resources including warm climate. The firstprotected area in Kenya, the Nairobi National Park was established in 1946. Today Kenya has 52 national parks and reserves. Most of the protected areas are located in the arid and semi-arid areas. Main preferred wildlife species include the elephants (see plate) which are currently threatened both by poaching and the expanding human activities in the protected areas' vicinity. Other attractions which are not yet well developed include historic sites, mountain climbing, hiking, bird watching, camel treks, guided nature walks, nature photography, boat, and manyothers. With the popularity of ecotourism, it is safe to assume that such activities will become popular tourists areas.

\section{Role of tourism in Kenya's economy}

Tourism is of fundamental importance to the national economy and to its developmentplans. Tourismiscurrently the largest single primary foreign exchange earner, moreimportantindividually than the three traditional export crops of coffee, tea, and horticultural produce. Kenya earns \$18 million a year in tourism revenues. The direct and invisible earnings account for 10 percent of Kenya's gross national product. Revenue from public parks and reserves is projected to increase from $\$ 23,6$ million in 1990 to $\$ 53,7$ million in 1995 (constant 1990 dollars) (Kenya Wildlife Services, 1990). Tourism employs about 1,3 million Kenyans, approximately $8 \%$ of wage earning labour force and offers prospects of a faster expansion of employment opportunities than in any other sector in Kenya. With one of the world's highest rates of population growth of about $3,7 \%$ per annum, and with half the total population of 26 million under the age of 15 , the need for new jobs is urgent. Tourism also generates development in neglected regions and contributes to the protection of natural resources. Wildlife, the primary tourist attraction in East and Central Africa, is protected largely as a result of tourism. Thus tourism justifies the establishment of the protected areas.

\section{Impacts of tourism on Kenya's natural environment}

Behind the tourism success in the national economy, are a multitude of problems that have necessitated the need for ecotourism. Such problems include:

- Low level of local community support for the parks and the wildlife. This results from lack of community involvement in the protected area management and in benefits from tourism revenue. Tourism revenue goes almost entirely to the national treasury.

- Inadequate funding and enforcement power of the authorities in charge of parks.

- Poaching, especially of elephants and rhinos that has reduced their populations. The elephant population in Kenya, which totalled 130000 in 1973 , has been reduced by $88 \%$ to 16000 , largely as a result of poaching. The rhino population has suffered even more severely, losing noless than 97,5 $\%$ of its total population of 20000 animals in 1970 to reach only 500 animals by early 1980 s. The rhino population recently started increasing following special protectivemeasures. It is expected that the rhino population will reach 680 by end of the century.

- Degradation of public lands that still contain wilderness for wildlife. Kenya's human population has increased tremendously from $14 \mathrm{~m}$ in 1970 to the current total of about 26 $\mathrm{m}$. Consequently the pressure on land has become very acure, including the land on which wildlife depends, and which in turn is the centre for much of the tourism. As a result natural wildlife habitat and migration routes are shrinking.

- Subdivision of land into individual holdings, especially in the wildlife dispersal areas adjacent to national parks and reserves, is an area of particular concern. 
In addition, many of the protected areas today face various internal degradation of thenaturalenvironment. Table 1 highlights some of the problems facing protected areas.

In attemps to integrate tourism and nature conservation, provide the needs of the country, and benefit the local people, the KWS prepared a five year plan, A Policy FrameworkandDevelopment Programme, 1991-96. The plan has not yet been put in action. The objectives of KWS as stated in the plan are:

- Toconserve the natural environment of Kenya and their fauna and flora, for the benefit of present and future generations and as a world heritage.

- Touse the wildlife resources of Kenya sustainably for the economic development of the nation and for the benefit of people living in wildlife areas.

- To protect people and property from injury or damage from wildlife.

Ecotourism is expected to play a role in the success of the KWS plan.

\section{Opportunities (Benefits) of Ecotourism to Kenyan Communities}

Oneof the central aims of this article was to establish the benefits that could accrue from ecotourism which will help reduce negative impacts of tourism on natural resources and promote local development in Kenya. The evolution of tourism and its growth in Kenya has been outlined above in order to establish the role of ecotourism in the country's economy. The negative impacts of tourism on the environment have been described. Drawing from observations made in the literature by several authors in recent years, the potential benefits from ecotourism rather than the traditional tourism in Kenya will include the following :

- Ecotourism will generate greater direct benefits to local communities than those arising from the conventional tourism. Local people will be more involved in tourism. Tourist will be integrated into the local communities. As a result the local communities will be more likely to support conservation measures in their areas. In the past local people have not received any direct benefit from tourism. Ecotourism will create more employmentopportunities generated and the development of new markets. There will be mutual involvement of local people and outside experts with local people and integral research studies. As a result, there will be local control of research, by and for the local people resulting further into local commitment and dedication to tourism development and natural resource protection. Local people will also benefit from selling souvenirs to tourists. In addition, more goods and services will be purchased locally. This will minimize money leakage abroad. There will also be greater use oflocal goods and facilities ecotechniques attributed to generating greater economic linkages with the local economy andenabling the local people to have more direct involvement in the industry - both as employees and as owners. The problem of isolation of regions will be overoome as tourism will facilitate provision of roads. It would offer long-term solution for peripheral regions and boosts the local economy while working toward preservation of a wilderness area.

- Small scale tourist facilities, owned and operated by the local people will bring tourism's economic benefits directly to the local area. Previously, huge facilities owned by multinational cooperations have been the order. Small scale facilities tend to generate little environmental negative impacts because of its small scale.

- Limited, highly controlled development and selective marketing attractionssmaller number of affluent tourist who spend more and stay longer than conventional tourists.

- The tourists industry will support conservation organization financially as an investment to further its own interestsin natural areas as attractions. As a result more protected natural and cultural areas will be established to meet the increased requirements of ecotourismand distribute thepotential demand for such areas.

- There will be more greater cooperation between tourist authorities and wildlife managers regarding the planningofnatural areas. They will actively contribute to efforts made by conservation groups to educating tourists to respect nature and maintain natural resources. More efforts will be made to involve schools, universities students and similar groups thereby raising awareness and contributing to the goal of conservation. Publication of materialsthat will explain thenatural resources and their attributes to the general Kenyan will increase. Ecotourism will also play a role in supporting education and professional training activities that deal with the tourism-conservation relationship such as guides and other park personnel courses.

- Ecotourism will help reduce the conflict between wildlife, protected areas and the local people in Kenya by compensating losses incurred due to wildlifedamage an provided economic incentives to local people for the forgone use of the resources of the protected area.

\section{Challenges: How can ecotourism work in Kenya?}

In order to be truly sustainable in Kenya, ecotourism development should:

- Ecotourism must meet the sustained needs of the national economy and of the local people in terms of improved living standards both in the short and long term periods.

- Ecotourism must satisfy the demands of the growing number of tourists and continue to attract them in order to meet the needs of the local people.

- Ecotourism mustsafeguard thenatural environment to continue attracting more tourists.

\section{Difficulties facing implementation of ecotourism}

Whereas ecotourism will possibly enable local participation and local development in Kenya, thereare several handicaps. First, is the international nature of ecotourists. Ecotourist originate from the more developed countries (MDCs). Most tourists activities in Kenya areowned and controlled by foreign organizationsind uding air-lines used to transport tourists. Payments for holidays expenditure are often made to travel agents and tour operators in tourist origin countries so that only a percentage reaches Kenya. In addition, payments for imports consumed by tourists in the country and remittance of profits interests and dividends to foreign owners of tourism 
Table 1

The Negative Effects Tourism in Kenya's Protected Are-1s

\begin{tabular}{|c|c|c|c|}
\hline Factor Involved & Impact on Natural Quality & Comments & $\begin{array}{l}\text { Example of } \\
\text { Protected Areas }\end{array}$ \\
\hline Crowding & $\begin{array}{l}\text { Environmental stress, animals } \\
\text { show changes in behaviour }\end{array}$ & $\begin{array}{l}\text { irritation, } \\
\text { reduction in } \\
\text { quality, } \\
\text { carrying } \\
\text { capacity limits, } \\
\text { displacement }\end{array}$ & $\begin{array}{l}\text { Amboseli, Masai } \\
\text { Mara }\end{array}$ \\
\hline Overdevelopment & $\begin{array}{l}\text { Excessive man-made } \\
\text { structures, intruding on } \\
\text { visual quality }\end{array}$ & $\begin{array}{l}\text { unsightly urban } \\
\text { concentrations, } \\
\text { reduced } \\
\text { aesthetic values }\end{array}$ & $\begin{array}{l}\text { Mwea, Keekerok } \\
\text { Ngai Ndethya }\end{array}$ \\
\hline Roads and Tracks & $\begin{array}{l}\text { Habitat loss, drainage } \\
\text { change, barriers to animals }\end{array}$ & aesthetic scars & $\begin{array}{l}\text { Kuinga Marine } \\
\text { biosphere } \\
\text { reserve, lake } \\
\text { Turkana }\end{array}$ \\
\hline $\begin{array}{l}\text { Access-motor } \\
\text { vehicles, } \\
\text { powerboats, } \\
\text { pedestrian }\end{array}$ & $\begin{array}{l}\text { Disturbance to animals, loss } \\
\text { of quiet, trail erosion } \\
\text { disturbs wildlife }\end{array}$ & $\begin{array}{l}\text { noise pollution, } \\
\text { loss of } \\
\text { wilderness } \\
\text { intergroup } \\
\text { conflict, } \\
\text { aesthetic impact }\end{array}$ & $\begin{array}{l}\text { Mt. Kenya, } \\
\text { Kichwa Tembo } \\
\text { area in Masa } \\
\text { Mara }\end{array}$ \\
\hline $\begin{array}{l}\text { Anti-social activity } \\
\text { noise, radios, etc. } \\
\text { litter }\end{array}$ & $\begin{array}{l}\text { Interference with natural } \\
\text { sounds, wildlife impairment } \\
\text { of scene, habituation of } \\
\text { wildlife to garbage }\end{array}$ & $\begin{array}{l}\text { irritation } \\
\text { aesthetic loss, } \\
\text { health hazard }\end{array}$ & Many areas \\
\hline Vandalism & $\begin{array}{l}\text { Mutilation and facility } \\
\text { destruction }\end{array}$ & $\begin{array}{l}\text { loss of natural } \\
\text { beauty }\end{array}$ & Many areas \\
\hline Vehicle speeding & Wildlife mortality, dust & $\begin{array}{l}\text { aesthetic } \\
\text { values, reduced } \\
\text { safery concerns }\end{array}$ & $\begin{array}{l}\text { Sibiloi } \\
\text { National Park }\end{array}$ \\
\hline $\begin{array}{l}\text { Driving-off-road } \\
\text { and night time } \\
\text { driving }\end{array}$ & $\begin{array}{l}\text { Soil and vegetation damage, } \\
\text { disturbance to wildlife }\end{array}$ & $\begin{array}{l}\text { loss of } \\
\text { wilderness, } \\
\text { disruption of } \\
\text { wildlife viewing }\end{array}$ & $\begin{array}{l}\text { Masai Mara, } \\
\text { Samburu, } \\
\text { Amboseli }\end{array}$ \\
\hline Feeding animals & $\begin{array}{l}\text { Behaviourial changes, poor } \\
\text { diet }\end{array}$ & $\begin{array}{l}\text { danger to } \\
\text { tourists }\end{array}$ & $\begin{array}{l}\text { Amboseli, } \\
\text { Nairobi, Masai } \\
\text { Mara }\end{array}$ \\
\hline $\begin{array}{l}\text { Souvenirs and wood } \\
\text { collection } \\
\text { Illegal logging } \\
\text { Trespass } \\
\text { Poaching } \\
\text { Urban expansion }\end{array}$ & $\begin{array}{l}\text { Removal of natural } \\
\text { attractions, disruption of } \\
\text { natural processes loss of } \\
\text { habitat. Small wildlife } \\
\text { mortality }\end{array}$ & $\begin{array}{l}\text { perceived } \\
\text { inappropriate } \\
\text { behaviour in } \\
\text { national park }\end{array}$ & All areas \\
\hline $\begin{array}{l}\text { Powerlines } \\
\text { Artificial water } \\
\text { holes and salt } \\
\text { provision } \\
\text { Introduction of } \\
\text { exotic species }\end{array}$ & $\begin{array}{l}\text { Destruction of vegetation, } \\
\text { erosion } \\
\text { Unnatural wildlife } \\
\text { concentrations, vegetation } \\
\text { damage }\end{array}$ & $\begin{array}{l}\text { Aesthetic } \\
\text { impacts }\end{array}$ & All areas \\
\hline
\end{tabular}


business. So although on paper some tour operators and hotels especially the Kenya owned like African tours and hotels have the objective of investing in and operating relatively undeveloped areas, and a policy of purchasing from local supplies wherever possible, the majority still import. Often their tour, travel and accommodation needs are largely coordinated by firms based in those countries. Consequently, whilst ecotourists may be affluent, much of their expenditure is not made in Kenya. It has been estimated that the portion of total inclusive tour price retained locally drops to only $22 \%-25 \%$ if both the airline and hotel used are foreignowned. Furthermore it has been pointed out that true wilderness tourist is a poor economic bet, because there is nothing to spend money on. In Kenya, most of the tourism investment is owned by foreign developers based in MDCs. These conditions pose difficulties in realizing the benefits of ecotourism. Second, is a problem of tourism development enclaves whereby some areas are preferred. Whilethismay be advantageous since the adverse effects of tourism are confined to clearly defined areas, it cause stress to the areas involved.

The third issue is the rapide growth of ecotourism itself. Kenyans tourists are rapidly growing. It is estimated that about 1 million tourist will be visiting the country per year. How will this be managed? Fourth is the issue of the demand and interests of the visitors. Visitor interests and satisfaction are crucial in continuing to attract tourists to a destination in order to provide the needed money. In addition, the tastes and needs of the tourist in terms of food and accommodation must be checked. In most tourist lodges in Kenya, even those in the remote areas attempts are made to provide the dishes as diverse as those of North American. No bodyexpects the tourist to risk their lives or use substandard facilities. How will the visitor satisfaction be maintained while promoting use of local staff?

\section{Some guidelines for sustainable ecotourism in Kenya}

It is important for future reference to introduce a careful monitoring programmes so that success and failures can be understood. Tourist need to be made more fully aware of the damaging potential of their stay and modify their behaviour and expectations accordingly. Tourism enter- prises need to ensure the environmental integrity of their operations via procedures such as environmental impact assessment and green auditing. One of the most important aspect in Kenya to ensure true sustainability of ecotourism and the resources upon which it is based is that the local people is involved in the management of the resources and benefit directly from the utilization of the resources. For local people to participate, we must understand their needs. They must be educated about the purpose of the projects and be given a voice in government decisions giving them control over resources and decisions that affect their lives.

There is also need to study how to educate the travellers, the tour operators to be more sensitive to the environment and conscientious guests rather than invaders. Thestandardsof behaviour of tourists must be promoted. There is need for information on the carrying capacity of nature reserves. There is need to know how many visitors an area can absorb. The vulnerability of species and habitats, problems of pollution, waste disposal, and the disruption of critical ecological processes by tourism are not clearly understood. There is need for environmental assessment to measure and reduce harassment levels. It is important toassess different areasin Kenya in terms of their potential and carrying capacities to determine level and type of tourism scale, ownership, location and timing of thevarious touristdevelopments. There is a danger of assuming that the ecotourist is automatically an environmentally sensitive breed. Certain types of ecotourists may be of less responsible behaviour.

There is need for coordination. All sectors involved induding KTDA, MTW, KWS, private enterprise, local communities, tour operators, conservation professionals, park managers, government officials, lodge owners, guides, researchers, consultants, and other professionals striving to implement ecotourism. NGOs must work together. At the moment, for instance, most hoteliers, tour operators and travel agents participate in their respective trade associations, the Kenya Association of Hotelkeepers and Caterers, Kenya Associations of Tour Operators (KATO) and Kenya Association of Travel Agents (KATA). These associations act as private sector pressure groups, engaging in such activities as lobbying the government to maintain and improve the quality of tourism infrastructure, for example roads and water availability. Ecotourism activities are intended to conserve natural areas, nativecultureor endangeredspecies. There isneed for a national tourism plan as partof an integrated planning strategy that include the envitonment and ecotourism guidelines.

\section{Conclusions}

The advent of ecotourism provides major opportunities to help minimize damage to Kenya'sdisappearingecosystems, maximize economic returns to the government, involve and benefit rural communities and help integrate conservation and development, but only if it is well planned and properly managed. If poorly managed, it may result in more profound damagesthan the traditional tourism as more peripheral natural areas of Kenya will be opened up forecotourism. There is need for additional research to help set guidelines for sustainable tourism activities and public participation. There is need for coordination of all the involved parties from the national to the grass-root levels. $f$

\section{REFERENCES}

BOO, Elizabeth, Ecotourism: The Potentials and Pitfalls, vols 1 and 2. Washington, D.C., World Wildite Fund, 1990.

CATER, E. Ecotourism in the Third World: Problems for Sustainable Tourism Development, Tourism Management, 14(2), 1999, pp. 85-90.

DAAKE, S. Local Participation in Ecotourism Projects, in Nature Tourism: Managing for the Environment, T. Whelan Ed, Washington, D.C., Island Press, 1991.

LINDBERG. K. Nature Tourism as an Agent for Sustainable Devalopment, New York, World Rescurces Institute, 1991.

OLINDO, P. The Old Man of Nature Tourism: Kenya, in Nature Tourlsm: Managing for the Environment. T. Whelan Ed., Washington, D.C., Island Press, 1990.

THORFELL, J.W., Protected Areas in East Africa : A Training Manuel. College of African Wildife Management, Tanzania, 1984.

WESTERN, D., Defining Ecotourism, in Ecotourism: A Gulde for Planners and Managers, K. Lindberg and D.E. Hawkins (eds). North Bennington, Vermont, The Ecotourism Society, 1993, pp. 7-11.

WHELAN, T., Ecotourism and its Role in Sustainable Development, in Nature Tourism: Managing for the Environment, T. Whelan Ed, Washington, D.C., Island Press, 1991.

WOALD COMMISSION ON ENVIRONMENT AND DEVELOPMENT (WCED), Our Common Future, Oxford, Oxford University Press, 1987. 